\title{
Research on Inheritance and Development for Chinese National Dance Culture
}

\author{
Chi Zhang ${ }^{1, a}$, Xiaojie Wang, ${ }^{2, b}$ \\ ${ }^{1}$ School of Education and Sports, Bohai University, Jinzhou, 121013, China \\ ${ }^{2}$ College of Art and Communication, Bohai University, Jinzhou, 121013, China \\ a378290420@qq.com, b1019813588@qq.com
}

Keywords: national dance culture; inheritance and development; existing problems; main measures

\begin{abstract}
Ethnic dance can effectively promote the exchange and integration of culture and become the link for people of all ethnic groups to communicate and communicate. The inheritance and development of the national dance culture is a long process and has a long way to go. Based on the inheritance of national dance culture, this paper proposes the lack of effective inheritance in the process of inheriting and developing Chinese national dance culture, the lack of correct understanding of national dance culture, the lack of professional performing arts and the commercialization of national dance. Based on the integration and development of national culture, respecting the traits of national dance culture, arranging ethnic dances into square dances that the masses like to see, integrating national dance culture into dance teaching, promoting the diversified development of national dance culture, and taking advantage of new media. Measures.
\end{abstract}

\section{Introduction}

Dance is a kind of performing arts, using the body to complete all kinds of elegant or difficult movements, generally with music accompaniment, with rhythmic movement as the main means of expression of art form. The art of dance expresses inner feeling in the action language of human body form and brings aesthetic taste to people. It is a form language that naturally integrates people's hopes, concepts and spirits into various cultural factors. This non-artistic behavioral action language, once formed into a stable style program, will be passed down from generation to generation and miraculously developed. This is the dance culture. The spirit of dance is a dancer who expresses people's thoughts and feelings and inner spiritual temperament through human body movement art and dance language. Chinese national dance has always been regarded as the "soul of national culture". Dance is the best carrier of communication. Through the collision and reference between different kinds, different nationalities and different regions, it can effectively promote cultural exchange and integration. It has become the link between people of all nationalities for communication and communication.

National dance is a national art bear and raised in ethnic minority areas. It is a true portrayal of the people's production and life. It has a strong national style and regional characteristics and reflects the unique historical heritage and cultural heritage of the nation. In the way of the words and deeds and the deafness, through the natural inheritance, the village inheritance, the family inheritance and the inheritance of the masters and apprentices, the inheritance in the villages and villages has a customary and natural way. With the development of the times and social progress, modern civilization and foreign cultures continue to infiltrate, the traditional lifestyles of ethnic minorities have undergone profound changes, and there has been an impact on the living conditions of national dances, as old artists have become older or have passed away, and foreigners The impact and influence of multiculturalism, national dance is also facing the crisis of inheritance and development, the existing inheritance model is difficult to completely preserve the national dance culture. Therefore, effective measures must be taken to protect and inherit the national dance culture. 


\section{Characteristics of National Dance Culture}

China has a long history, large number of ethnic groups and a vast territory. Therefore, the national dance culture is rich and colorful, with the following characteristics:

(1) Singing and dancing, free and lively. One of the most prominent features of Chinese folk dance is the close integration of dance and singing. This form of singing and dancing is free, vivid and lively. It is easier to express more life content than pure dance, and it is easy to understand and loved by the masses.

(2) Skillfully using props and combining skills. Many ethnic dances in China use clever props, including fans, handkerchiefs, long silks, tambourines, single drums, flower sticks, lanterns, umbrellas, etc. These props enhance the artistic expression of dance, making dance movements more beautiful and beautiful. Variety.

(3) The plot and the image are vivid. Chinese folk dances attach great importance to content, and most of them have certain stories and legends as their basis. The characters are vivid and outstanding. Although some dances only express one kind of emotion, they are mostly presented as a complete storyline.

(4) Self-entertainment and entertainment, meaning unity. Many ethnic dances in China are the unity of self-entertainment and performance. Some dance activities are self-entertainment for the dancers, but also for the performance of the audience. Therefore, the dancers pay attention to the improvement of the dance skills and promote the development of the national dance.

(5) Impromptu play. Ethnic dances in various regions of China, although they all have certain formats and norms, they all have improvisational traditions. In particular, some ethnic dancers have more outstanding performances, emotional moments, and frequent performances. Glorious dance.

\section{Inheritance Law of National Dance Culture}

National dance can always clearly convey people's emotions, beliefs and aesthetic perspectives, and its inheritance has the following rules:

(1) Regional. Chinese folk dance has been inherited and developed for thousands of years, and the national dance culture is constantly enriched and changed. In the inheritance of the national dance culture, it fully embodies the regionality, that is, it is passed down in the specific life area of the nation and is full of the life history of the people of all ethnic groups. Only in a relatively fixed cultural atmosphere can we deeply understand and feel the cultural essence of our nation, and then accurately grasp the basic characteristics of national dance.

(2) Vulnerability. The inheritance of the national dance culture is fragile, mainly referring to the fact that it is easier to be damaged by the invasion of war in the era of frequent wars. There are still large number of feudal remnants in the society. It is considered that the national dance culture is a non-business or feudal superstition. It is just a pastime. Since the reform and opening up the national dance culture has been invaded by Western foreign cultures, which has made China's national dance culture face the predicament of survival.

(3) Instability. Instability mainly refers to the influence of the quality of the people. In some economically underdeveloped areas, the inheritance of the national dance culture still retains the traditional concept and believes that the inheritance of the national dance culture is a waste of resources, so it does not pay attention to personnel training and capital investment. In some areas, the ethnic dance culture has been eagerly aggravated, and more consideration has been given to the economic interests of the national dance culture, which has a negative impact on the inheritance of the national dance culture.

(4) Developmental. National dance is passed down in the development of social civilization. Different social development stages have given birth to different social civilizations. With the continuous improvement of people's cultural needs, the function of national dance has also changed, and with the development of social economy, new development space has been obtained. Under the new situation, the content and form of ethnic dances are naturally integrated into new content and ideas. While inheriting the tradition, they are advancing with the times, reflecting social development and changes in the times. 


\section{Existing Problems on Inheritance and Development for Chinese National Dance Culture}

There are many problems in the inheritance and development of Chinese national dance culture, which are highlighted in the following aspects:

(1) Lack of effective means of inheritance. The current national dance culture inheritance mainly relies on individual or social forces. The art types of integration are too complicated, the professional guidance for ethnic dance is not enough, and the performance platform and living space provided by young performers are limited. From the perspective of the inheritance of national dance and national culture, it is not conducive to the sustainable development of national dance, which is detrimental to the in-depth study of the original culture.

(2) Lack of a correct understanding of the national dance culture. China's national dance culture is rich and colorful, but due to the differences in national culture, this difference is also directly reflected in the national dance. Some dance artists and national cultural researchers have a superficial understanding of ethnic dances, lack of in-depth research and research, do not have the ability to inherit national dances, and do not have the ability to innovate and develop, which has a greater impact on the inheritance and development of national dance culture. influences.

(3) The lack of professional performance art. Many people think that national dance has a certain superstitious color. It is a kind of folk cultural activity that is self-entertainment and does not have the value of inheritance and development. The number of professional performers is small, and the performance artists are lost, which makes the national dance into a situation of unsustainable development. When various ethnic cultures and arts exchanges and exhibitions, although the title of the original ecology or ethnic dance, the reality is that the performance content is superficial, the essence of national dance is difficult to present.

(4) Ethnic dance tends to be commercialized. Commercialization is based on a certain industry, with profit as the ultimate goals, and plays an important role in promoting economic development and improving people's lives. With the improvement of China's economic level, people pay more and more attention to spiritual pursuit and enjoyment, and begin to explore national culture. Ethnic dance is a cultural phenomenon, but many cultural institutions or tourist attractions in order to seek benefits, commercialization of national dance does not attract mass consumption, and lose the charm of national culture.

\section{Main Measures on Inheritance and Development for Chinese National Dance Culture}

In view of the problems existing in the inheritance and development of Chinese national dance culture, based on relevant theories and with reference to previous research results, the main measures proposed in this paper are as follows:

(1) Based on the integration and development of national culture. The entry of socialism with Chinese characteristics into a new era is not only the integration of social economy and culture, but also the refinement of the essence of national culture and the preservation of the characteristics of national culture. Firstly, ethnic dances add modern aesthetic appeal to a deeper cultural path while retaining national characteristics. Secondly, the exploration and development of advancing with the times makes the singular artistic expression characteristics modern, entertaining and popular. In the end, driven by the concept of innovation and development, we must not only broaden our horizons, expand the living space of the national dance culture, but also break the national boundaries, move towards a larger stage of performance, and step into the international development path.

(2) Respect the traits of the national dance culture. Under the background of multicultural integration, how to effectively inherit and develop the national dance culture has become a topic of concern to the society and scholars. Fully understand the traits of national dance culture, maximize the sense of national culture, and vigorously promote the continuous innovation of national culture. At the same time, the national dance culture has unique national characteristics and connotations, and its expressions are also different. The inheritance and development of the national dance culture must fully respect the existing differences and dig deep into the inner cultural essence.

(3) Arrange the national dance into a square dance that the masses love to see. Square dance is 
the largest system in dance art. It is named after the gathering in the square. It integrates self-entertainment and performance and takes group dance as the main form of performance, with the main purpose of entertainment and body and mind. Square dance is a kind of fitness dance that people generally participate in. There are many dance elements, including ethnic dance, modern dance, street dance and Latin dance. The mass line is a shortcut to the inheritance and development of national dance. In-depth study of ethnic dance, select the part that is suitable for square dance, arranged into a square dance that the masses like to see and hear. The masses inherit the national dance culture while exercising, and it is also the inheritance and development of the national dance culture.

(4) Integrating ethnic dance culture into dance teaching. Dance teaching is an important way to inherit and develop national dance. Relevant dance institutions and art colleges should attach great importance to the training and teaching of ethnic dances, formulate corresponding teaching plans and programs, and refine the different national style characteristics and dance training content. In the process of teaching, dance teachers strengthen the integration of various disciplines, analyze the development of folk dances and cultural background from the perspectives of folklore, sociology and aesthetics, learn from others, innovate and inspire more national dances. The characteristics of the times make the teaching of folk dance more vivid. At the same time, carry out practical activities, conduct on-the-spot investigations, and explore the local customs, customs, and religious beliefs of the localities, and feel the simple national culture.

(5) Promote the diversified development of the national dance culture. Cultural pluralism refers to a country or a nation that, in the process of social development, inherits the excellent culture of the nation and combines the outstanding cultures of other countries or nations, thereby forming a national or national culture, supplemented by foreign cultures. A harmonious social atmosphere in which hundreds of schools contend. Affected by the diversified development of the world, the Chinese national dance culture is experiencing the impact of foreign art and market economy, and constantly shifts to a higher spiritual level. Some ethnic dances have become a way for people to entertain and entertain. Some ethnic dances have been adapted to become a sport for people to keep fit. The artists also adapted the ethnic dances to enhance the artistic expression and spiritual level of the national dance, so that the national dance has a broader development space. The national dance culture is shifting from "vulgar" to "elegant" to a higher level of aesthetic realm and will eventually go to the world with a national character and personality.

(6) Take advantage of new media. Compared with traditional media, new media is a media form developed by traditional media such as newspapers, radio, television, etc., using digital technology, network technology and mobile technology, through the Internet, wireless communication networks and cable networks, and computers. Terminals such as mobile phones and digital televisions provide users with information and entertainment forms and media forms. The new media uses a variety of animated virtual technologies to bring joy and beauty to people, making people feel more persistent when they leave the dance scene. National dance should seize the opportunity of development and continuously improve its mode of communication. At the same time, with the elements provided by various media platforms to create, the content is richer and fuller. Combining traditional national dance art with science and technology, opening up new roads, bringing new visual impact to the audience, providing new opportunities for the inheritance and development of national dance.

\section{Conclusion}

The economy and society are constantly developing, and the national dance culture has also been passed down from generation to generation, providing possibilities for long-term development. At present, the national dance culture in China mainly develops in two directions: First, the popular culture direction, the national dance culture has a strong mass and entertainment, which determines the popular characteristics of the national dance. "National dance everyone jumps" has gradually become an important boost for the development of national dance. Therefore, it is necessary to promote the development of national dance culture towards popular culture. Second, the direction 
of the elite culture, this dance requires beautiful craftsmanship and elegant performance, which can reflect the national spirit and the characteristics of the times. It is necessary to integrate folk songs and epics into national dances and express the spiritual realm and thoughts and feelings of national dances in a modern way.

The inheritance and development of the national dance culture is a long process. It has a long way to go. It requires the passion of the national dance workers and the active participation of the people. Fully understand the importance of national dance culture, and conscientiously study the essence and connotation of national dance culture. While inheriting and developing, we must not only strengthen our stance, but also retain the traditional national characteristics. We should also have an open spirit and actively integrate into the new era elements. Inheritance and innovation coexist, creating a national dance culture that is close to the spirit of the times and reflects the profound cultural characteristics of the University.

\section{Acknowledgement}

This work is supported by social science fund project of Liaoning province (L17CMZ002): Innovation measures on promote the outstanding national dance culture going out under the "One Belt and One Road" strategy.

\section{References}

[1] Q. L. Li, "On the Inheritance and Development of Chinese National Folk Dance Culture," Song of the Yellow River, vol. 28, no. 11, pp. 102-103, 2018.

[2] L. L. Jiang, "Inheritance and Development of National Dance Culture," Journal of Lanzhou University of Arts and Science(Social Science Edition), vol. 33, no. 4, pp. 125-128, 2017.

[3] L. Ye, "The Inheritance and Development of Folk Dance in the New Media Age," Journal of Hubei Correspondence University, vol. 30, no. 24, pp. 192-194, 2017.

[4] Q. Y. Li, "Thoughts on the Development and Inheritance of Yunnan Minority Dance under the Information Environment," Journal of Changchun University of Science and Technology, vol. 8, no. 4, pp. 138-139, 2013.

[5] H. Liu, "Research on the Inheritance and Development of National Dance Culture," Art appreciation, vol. 19, no. 12, pp. 101-102, 2017.

[6] M. H. Li, "The Inheritance and Development of Regional National Dance in Local Colleges and Universities," Modern Music, vol. 34, no. 4, pp. 110-111, 2018.

[7] L. Dai, "An Analysis of the Inheritance and Development of National Dance Culture," Participation flowers, vol. 36, no. 11, pp. 145-146, 2016. 